\title{
The Sweet Potato Substitution of Raw Material of Food Processed and Consumers Preferences
}

\author{
Triwara Buddhisatyarini \\ Department of Agribusiness \\ Universitas Muhammadiyah Yogyakarta \\ Yogyakarta, Indonesia \\ triwarabs@gmail.com
}

\author{
Nur Rahmawati \\ Department of Agribusiness \\ Universitas Muhammadiyah Yogyakarta \\ Yogyakarta, Indonesia \\ Rahma_wati_mf@umy.ac.id
}

\author{
M Thoha \\ Department of Agribusiness \\ Universitas Muhammadiyah Yogyakarta \\ Yogyakarta, Indonesia
}

\begin{abstract}
This research aims to know the consumer preference of foods, based on the level of sweet potato substitution of raw material for food product, and to know the profit of this product. Product of sweet potato substitution to be analyzed this research are pizza, brownies, and bread. To collect the sample the researcher conducted accidental quota sampling method. Data were collected from consumers who try the product. The consumers amounting to 60 people were required to fill the questioner (40 students of UMY, 10 Lecturers, and 10 staffs).On the basis of the research, it is revealed that pizza consumers are most likely to choose D substitution ( $80 \%$ sweet potatoes $20 \%$ wheat), brownies consumers mostly prefers $\mathrm{C}$ substitution $(60 \%$ sweet potatoes $40 \%$ wheat), and bread consumers mostly prefer on $\mathrm{C}$ substitution $(60 \%$ sweet potatoes $40 \%$ wheat). This result is based on consumer preferences. This preference may be referred substance for the producer to release their product. Producing D substitution of pizza $(80 \%$ sweet potatoes $20 \%$ wheat) can earn a profit of $72,1 \%$. For C substitution of brownies $(60 \%$ sweet potatoes $40 \% \mathrm{w}$ wheat) the profit is $95,4 \%$. On the production of $\mathrm{C}$ substitution of bread, producers can get the profit of $110 \%$.
\end{abstract}

Keywords: sweet potato's substitution, consumer preferences, profit

\section{INTRODUCTION}

The development of farming will have an impact on the development of agro-industries that can lead to market opportunities for their processed products. One sector that can be a mainstay in the development of agro-industry in Indonesia is the downstream industry, namely the processed food industry [1].

The import processed food inundating the domestic market is a challenge to face by industrial business owners, especially small-scale industries of food processing, so that they can still compete and try to control the local market. Of course, it is highly expected that they continue to rely on and utilize local raw materials as industrial raw materials [2]

Until now, the main raw material for processed food products that are quite popular are wheat flour/wheat, since it is always considered more superior than other raw materials. Unluckily, we know that wheat flour is entirely derived from imports, because Indonesia does not produce wheat as a basis for wheat flour.

Sweet potatoes have become one of the local raw materials that can be processed into processed foods with high quality and taste, and they are able to compete with processed food products from flour. However, there the upper middle class society may consider sweet potatoes and cassava as inferior food ingredients, making them reluctant to consume them [3]. Unlike the Indonesians considering sweet potatoes as the food of the poor, the people of developed countries like Japan are even very fond of sweet potatoes because they certainly know their the benefits. In Japan, sweet potatoes have been processed as corn flakes. The sweet potato formed by a $1 \mathrm{~cm} 3$ cube is processed and dried. To be consumed, the people will only have to pour milk or hot water onto the dried yam. The food has become one of the most widely consumed foods that among Japanese people and some other developed countries.

Local food products have great potential to replace imported foodstuffs that have been consumed by the public [2]. The results of the development of processed food, sweet potatoes, can be processed into high-grade and high-economic processed foods such as brownies, pizza, bread, and ice cream, and also jams, sauces and noodles that can compete with imported processed foods. The development of processed sweet potato food is still relatively new. Hence, it is necessary to find the composition of the use of raw materials that can substitute sweet potato to flour to obtain processed food products that are preferred by consumers. On this basis, it is expected that people will reduce the use of flour as the main raw material to be replaced by sweet potatoes. This will definitely reduce dependence on flour. However, the replacement of some of the main raw materials with sweet potatoes will certainly cause changes in the texture, taste, and appearance which will affect consumer preferences. This will ultimately affect the profits of the producers.

Based on the above description, the researcher would like to conduct a research based on the following objectives:

1. To know consumer preferences for processed foods with various levels of combination between jaiar sweet potato and flour.

2. To find out the costs and benefits of processed food business with various combinations of sweet potatoes and flour.

3. To know the relationship between consumer preferences and costs and benefits of processed food businesses with various combinations of sweet potatoes and flour.

\section{A. Sweet Potatoes (Ipomoea batatas L)}

The sweet potato (Ipomoea batatas L) including the family Convolvulvaceae, kind of plants of annual crops, that have a main structure consisting of stems, are round, not woody, with books and types of upright growth or creeping. The stem color is usually dark green to purple. Sweet potato flesh is white, yellow or orange slightly purple, the ideal form of yam is rather long and weighs between $200 \mathrm{~g}-250 \mathrm{~g}$ per yam [4]. Sweet potatoes, including tubers, are cheap and rarely included in the family menu, whereas in the kitchen of Westerners and 
Japanese, sweet potatoes are prima donna and are relatively expensive. During festivals, such as Christmas and Thanksgiving Day, US residents commonly make exclusive offerings of sweet potatoes such as cakes, pastries, complementary purees, steak or salad, ice cream, pudding, muffins, soufflés, pancakes, croquettes, crispy soup, and mattpun as sprinkling of grilled dishes [5]

The sweet potatoes have a very high advantage and benefit for Indonesians. Some of the superior sweet potatoes include:

1. Sweet potatoes are easily cultivated on a variety of land with autara productivity of 20-40 tons / ha in the form of fresh tubers.

2. The calorie content per $100 \mathrm{~g}$ is quite high,that is 123 cal and can give a feeling of fullness in a consumming of relatively small amount.

3. Sweet potato dishes is easily served, practical and variative, and compatible with other foods.

4. Each unit of sweet potato is cheap per-unit and is easily available on the market.

5. Sweet potatoes can function properly as a substitute and supplementation of traditional carbohydrate food sources from rice.

6. Sweet potatoes are not a new type of food and have been treated by the people of Indonesia since the long time ago.

7. Sweet potatoes contain vitamins and minerals that are high enough so that they are worthy of being considered as healthy foodstuffs. [3]

The disadvantage that is often expressed is the feeling of discomfort in the stomach for those who are not used to eating sweet potatoes and the emergence of flatulence. However, for those who have been accustomed to consuming sweet potatoes, such strange taste is not found. In Japan, Europe. and the United States, sweet potatoes are highly considered as the most preferable, even above potato fosods.

Table 1. Nutrient and calorie content of sweet potatoes compared to rice, cassava and corn per $100 \mathrm{~g}$ of ingredients

\begin{tabular}{|l|c|c|c|c|c|c|c|}
\hline Matrial & $\begin{array}{l}\text { Calorie } \\
\text { s (kal.) }\end{array}$ & $\begin{array}{l}\text { Carboh } \\
\text { idrate } \\
(\mathbf{g})\end{array}$ & $\begin{array}{l}\text { Protein } \\
(\mathbf{g})\end{array}$ & Fat (g) & $\begin{array}{l}\text { Vitami } \\
\text { n A (SI) }\end{array}$ & $\begin{array}{l}\text { Vitamin } \\
\mathbf{C}(\mathbf{m g})\end{array}$ & $\begin{array}{l}\mathbf{C a} \\
(\mathbf{m g})\end{array}$ \\
\hline $\begin{array}{l}\text { Sweet } \\
\text { Potato }\end{array}$ & 123 & 27.9 & 1,8 & 0.7 & 7000 & 22 & 30 \\
\hline Rice & 360 & 78,9 & 6.8 & 0.7 & 0 & 0 & 6 \\
\hline $\begin{array}{l}\text { UHL } \\
\text { Wood }\end{array}$ & 146 & 34,7 & 1.2 & 0.3 & 0 & 30 & 33 \\
\hline $\begin{array}{l}\text { Corn } \\
\text { (Yellow } \\
\text { (n) }\end{array}$ & 361 & & 8.7 & 4.5 & 350 & 0 & 9 \\
\hline
\end{tabular}

In addition to the nutritional content described in the label above, sweet potatoes have advantages in terms of their fiber content. The fiber content of sweet potatoes in sweet potatoes is $[7.85 \%(\mathrm{db})$ while wheat flour is $3.37 \%(\mathrm{db})$. This provides information that sweet potatoes can be used as food sources that have high food fiber that can be used as fiber-rich foods to prevent degenerative diseases [6].

\section{B. Consumer Preferences}

The theory of preference reveals thatconsumer preferences can be deduced from a number of observations that are sufficiently the choice or purchase on the market, without any desire to investigate individual preferences directly [7]. For example, if a consumer is observed when buying a combination of $\mathrm{A}$ and not a combination of $\mathrm{B}$, and $\mathrm{A}$ is not cheaper than $\mathrm{B}$, then for this consumer, $\mathrm{A}$ is preferable to $\mathrm{B}$. The preference theory is standardized in the following assumptions:

1. Individual taste do not change during a certain period,

2. Individuals are consistent, in that if the consumer observed prefer combination of $\mathrm{A}$ to combination $\mathrm{B}$, this consumer would never like B rather than A.

3. Individuals are transitivites; if $\mathrm{A}$ ismore preferrable to $\mathrm{B}$ and $\mathrm{B}$ is preferred to $\mathrm{C}$, then $\mathrm{A}$ is preferred to $\mathrm{C}$

4. Finally, consumers can be encouraged to buy a combination of items even though the price is attractive.

Agro-industry is the processing of agricultural products and therefore agro-industry is part of the six agribusiness subsystems agreed upon so far, namely the subsystem of providing production facilities and equipment, dance business, processing of products (agro-industry), marketing, facilities and coaching [8].

This study concerns more on food processing management because processing agricultural products in this case sweet potatoes become processed food products with quality and economic value, namely pizza, brownies, and bread by substituting with flour.

\section{Business Analysis}

a. Cost

The production cost is the entire cost that must be issued by the producer to obtain the production factors and the other supporting materials that will be utilized so that certain planned products can be carried out properly [9]. Meanwhile, production costs are all sacrifices used in the production process, expressed in money according to the prevailing prices [10]. Then based on the kind, costs in an industry, consist of:

1. The cost of consumable production facilities, namely all production facilities which are used up once in the value of the production process like raw materials, fuel, and so forth.

2. There is a depreciation of equipment or a reduction in value due to the time and method of use of all tools.

\section{b. Revenue}

Revenue is the results of sales the number of products. The total revenue, which is the total of the sales proceeds, can be written as:

$$
\begin{aligned}
& \text { TR = P. Q } \\
& \text { Which: } \\
& \text { TR = Total Revenue } \\
& \text { P = Price } \\
& \text { Q = Quantity }
\end{aligned}
$$

\section{c. Profit}

Profit is the difference between total revenue and total costs, both explicit and implicit costs. To calculate profits, it is possible to write the following:

$$
\pi=\mathrm{TR}-\mathrm{TC}
$$


Which:

$$
\begin{aligned}
& \pi=\text { profit } \\
& \mathrm{TR}=\text { total revenue } \\
& \mathrm{TC}=\text { total cost }
\end{aligned}
$$

Research on consumer preferences for soybeans, namely tofu and ternpe, reveals thateach have soybean type and there is a nature preferences as raw material. Soybeans desired by the tofu industry are those that are yellow, have large seed size, and thin skin. Soybeans with greenish yellow and green seeds and medium and small seed sizes were also selected by some respondents [11].

The research in the case study at CV. Citra Pangan Mandiri, suggest that the analysis of consumer preferences showed that brand awareness of Tropikool brand jelly products was still low compared to other brands [12].

The research of entitled Production Planning Model on the Supply Chain of Crude Palm Oil Considering Decision Making Preferences, developed model involving decisionmaking preferences in production planning through five types of attitudes, namely very optimistic, optimistic , ordinary, pessimistic and very pessimistic [13].

In the current era of globalization, the use of wheat flour as a basic material for the production of processed foods is felt to be burdensome to food processing producers if they always depend on wheat flour which is expensive and must be imported. Sweet potato is an agricultural commodity that has bright prospects, because besides being able to be used as foodstuffs it can also be projected as an industrial product for processed products. Sweet potatoes can be used as a substitute for staple foods because they are an efficient source of calories. In addition, sweet potatoes also contain sufficient amounts of vitamin A, ascorbic acid, tianine, riboflavin, niacin, phosphorus, iron, and calcium. In addition to donating vitamins and minerals, carotene levels in sweet potatoes as the main ingredient in the formation of vitamin A are in line with carotene in carrots (Daucus carota) [14].

\section{METHODS}

In the first research, there was manufacture of products with various substitutions using the experimental method. On the other hand, to know the consumer preferences the researcher conducted survey methods or commonly referred to as descriptive surveys which are data collection methods obtained directly from data sources using oral and written questions. This research was conducted in Yogyakarta with students, lecturers and staff respondents from Muhammadiyah University of Yogyakarta.

The numbers of respondents were 60 people consisting of 40 students, 10 lecturers and 10 employees. To get the respondent the researcher used the Accidental Quota Sampling technique. Data were collected from the respondents after they consumed sample products, and fill out the questionnaires that have been prepared.

Local sweet potato processed foods to be tested to consumers, were pizza, brownies and bread. It was done by way of comparing the substitution of sweet potatoes and wheat flour as follows:
Table 2. Comparison of substitution of sweet potatoes and flour

\begin{tabular}{|c|c|}
\hline Sweet potato & Wheat Flour \\
\hline $20 \%$ & $80 \%$ \\
\hline $40 \%$ & $60 \%$ \\
\hline $60 \%$ & $40 \%$ \\
\hline $80 \%$ & $20 \%$ \\
\hline
\end{tabular}

The results of various sweet potato substitutions in processed food production reveal the costs, revenues and profits that are influenced by prices. The substitution also produce finished products that give rise to consumer preferences and make a basis for an assessment of texture, appearance, and taste. From the finished product, producers will receive revenue that is influenced by prices and generate profits. Based on consumer preferences, it is revealed sweet potato processed food products with which composition will be produced in order to meet the needs of consumers.

\section{RESULT AND DISCUSSION}

\section{A. Consumers' Profile}

Consumers' profiles are part of the consumer biodata which contain the name, gender, age, level of education, origin, income, and so forth. In this study, 60 respondents were used as consumers to assess sweet potato processed foods consisting of 10 UMY campus employees (16.65\%), 10 UMY lecturers (16.65\%), and 40 UMY students (66, 77\%), consumer grouping was based on occupation, age, status, income level and regional origin.

Employees who were respondents in this study were UMY employees, most of whom were diploma and under graduate, $(90 \%)$ and equivalent of senior high school $10 \%$ only. Consumers' age is quite varied, $40 \%$ of employees are between 43-50 years old and the remaining 35-42 years old are $40 \%$. Most of them are married and male (90\%). In terms of income level $50 \%$ of consumers have income between Rp500,000 - Rp1,000,000 per month and this greatly influences the level of ability to consume or purchase power in their daily lives, even 40\% earn more than Rp1,000,000 and only $10 \%$ have less income than Rp. 500,000 per month.

Lecturer respondents constituted of those with $100 \%$ have formal education, and more than 12 years or averages are Postgraduate. The 50\% of them are between 43-50 years old and $90 \%$ of them are married. The lecturer income is above Rp1.000.000 for each month. 70\% of lecturers respondent are female and 50\% stay in Yogyakarta.

Student respondents constituted of $100 \%$ aged between 18-26 years, who are not married. $62.5 \%$ are male and $37.5 \%$ female. The student income is based on parental transfers they get every month and the amount varies greatly. $65 \%$ of students earn between Rp500.000 - Rp1.000.000 and 22.5\% earn more than $\mathrm{Rp} 1.000 .000$. This is because $70 \%$ are students from outside Yogyakarta so that students' monthly consumption fee is based on the ability of parents. Each student has $12.5 \%$ income of less than Rp500.000 because they are native Yogyakartanese or they live with parents. 


\section{B. Consumers' Preference Analysis}

Preference or taste is a concept, which is used in social, especially economic, assuming a reality or imaginary choice between alternatives and the possibility of alternative warnings. Consumer preference is obtained based on a consistent assessment of texture, appearance, taste, and price on processed foods. In this research, the researcher used 4 quality standard items to be evaluated, which are: texture, appearance, taste and price. The difference of this study and that conducted is that this research addresses consumers' preferences of Kencana and $\mathrm{ABC}$ soybean's sauce, using 6 quality standard items, and 3 of which are taste, price and appearance, the same as that in this research [15].

Basically the research suggest that the consumers are buying Teh Botol Sosro because of 6 quality standards, which are trade mark, product availability, taste, package security, labelling and firm reputation [16].

The result of the research about consumers' preferences of Mc Donald restaurant revealed thatthere are 5 factors influencing the decision making to buy product, namely: menu, parking area, price and service [17]. The other result of other research suggests that the consumption of cow meat ball have 4 factors of satisfaction, which are quality, venue, price and ease to get.

Sweet potatoes substitution of processed food in this case is, pizza, brownies, and bread. Texture is a collection of parameters to determine the quality of sweet potato processed food products based on their softness. The score used is 1 is very hard and 4 is soft. Appearance is the performance of the sample processed products, which can be measured based on consumer interest in the product, the score used 1 is not attractive and 4 is very interesting. Taste is one of the aesthetic judgments obtained when consuming processed food sample products so that it can judge whether the processed food products are delicious or not, the score used 1 is very unpleasant and 4 delicious. Price is the value of a sample product that is determined by money, the score used is very cheap and 4 is expensive.

The composition of substitution in processed sweet potato food as follows:

a. Substitution A: $80 \%$ flour $20 \%$ sweet potatoes

b. Substitution B: $60 \%$ flour $40 \%$ sweet potato

c. Substitution of C: $40 \%$ flour $60 \%$ sweet potato

d. Substitution D: $20 \%$ flour $80 \%$ sweet potato

Based on the average score of consumer preferences in table 3 consumers prefer pizza products with a substitution of D: $80 \%$ sweet potato $20 \%$ flour. Consumer assessment which states that they prefer the substitution of $\mathrm{D}$ can be seen from the consumers' assessment of higher flavor and texture, and the highest average, but in terms of appearance is rather less preferred. That is different with result of [18], which shows that consumers prefer the doughnut which is made of pure $(100 \%)$ wheat flour than product made of $30 \%$ or $50 \%$ mocaf substitution.
Table 3. Average Score of Consumer Preference on Pizza Products

\begin{tabular}{|l|c|c|c|c|}
\hline \multirow{2}{*}{} & \multicolumn{4}{|c|}{ Pizza substitution } \\
\cline { 2 - 5 } & $\mathrm{A}$ & $\mathrm{B}$ & $\mathrm{C}$ & $\mathrm{D}$ \\
\hline Texture & 2,2 & 2,7 & 3 & 3,2 \\
\hline Appearance & 2,5 & 2,9 & 3 & 2,8 \\
\hline Taste & 2 & 2,7 & 3,1 & 3,3 \\
\hline Price & 2,5 & 2,5 & 2,4 & 2,6 \\
\hline Average & 2,3 & 2,7 & 2,9 & 3 \\
\hline
\end{tabular}

\section{Brownies}

Consumer preference for brownies products can be seen based on consumer ratings in table 4 with the following average scores.

Table 4. Average Score of Consumer Preference on Brownies

\begin{tabular}{|l|c|c|c|c|}
\hline \multirow{2}{*}{} & \multicolumn{4}{|c|}{ Brownies Substitution } \\
\cline { 2 - 5 } & $\mathrm{A}$ & $\mathrm{B}$ & $\mathrm{C}$ & $\mathrm{D}$ \\
\hline Texture & 2,2 & 2,7 & 3,2 & 3,3 \\
\hline Appearance & 2,2 & 2,7 & 3,3 & 3,3 \\
\hline Taste & 2 & 2,7 & 3,3 & 2,5 \\
\hline Price & 2,5 & 2,5 & 2,4 & 2,3 \\
\hline Average & 2,2 & 2,7 & 3 & 2,8 \\
\hline
\end{tabular}

Based on the average score of the assessment of consumer preferences in processed brownies, the comparison shows that respondents prefer C: $60 \%$ substitution of sweet potatoes $40 \%$ flour, in substitution $\mathrm{C}$, respondents prefer based on their taste and appearance. But in terms of texture, they prefer $80 \% \mathrm{D}$ substitution of sweet potatoes $20 \%$ flour because it is softer than other substitutions.

\section{Bread}

The average score of consumer preference for sweet potato-substituted bread can be seen in table 5. It is obvious that the average score of consumer preferences is based on the assessment given by consumers,

Table 5. Average Score of Consumer Preference for Bread Products

\begin{tabular}{|l|c|c|c|c|}
\hline \multirow{2}{*}{} & \multicolumn{4}{|c|}{ Bread Substitution } \\
\cline { 2 - 5 } & $\mathbf{A}$ & $\mathrm{B}$ & C & D \\
\hline Texture & $\mathbf{2 , 2}$ & $\mathbf{2 , 5}$ & $\mathbf{3 , 2}$ & $\mathbf{3 , 1}$ \\
\hline Appearance & $\mathbf{2 , 8}$ & $\mathbf{2 , 8}$ & $\mathbf{2 , 9}$ & $\mathbf{2 , 6}$ \\
\hline Taste & $\mathbf{2 , 4}$ & $\mathbf{2 , 7}$ & $\mathbf{3 , 2}$ & $\mathbf{2 , 9}$ \\
\hline Price & $\mathbf{2 , 5}$ & $\mathbf{2 , 3}$ & $\mathbf{2 , 5}$ & $\mathbf{2 , 6}$ \\
\hline Average & $\mathbf{2 , 4}$ & $\mathbf{2 , 6}$ & $\mathbf{2 , 9}$ & $\mathbf{2 , 8}$ \\
\hline
\end{tabular}

Based on the average score obtained from respondents' assessment, it can be seen from table 5 that respondents prefer processed food substituted with sweet potato bread with $\mathrm{C}$ $60 \%$ substitution of sweet potato $40 \%$ flour In this sweet potato processed food food, it seems that consumers prefer $\mathrm{C}$ substitution because of their assessment on texture, taste, and 
appearance which gives a higher score compared to other substitutions.

\section{E. Total cost}

Costs lead to different results for each substitution composition. The more flour used, the higher the costs incurred and the sweeter potatoes used the lower the costs incurred. The cost of the main raw materials is subject to change, so that each substitution occurs in a cost difference. The cost of supporting the product is not affected by the substitution composition.

\section{F. Revenue}

In the revenue from the sale of processed food with sweet potato substitution, there is no difference in revenue from each substitution, because the selling price of each substitute product is the same.

\section{G. Profit}

Profit is the result of revenue that has been deducted from costs incurred from production resulting in a nominal profit. The benefits of each product vary because of different production costs but the product selling price is fixed. The profits obtained by producers when producing processed food based on consumer preferences are: producing substitute pizza D ( $80 \%$ sweet potato $20 \%$ flour) the profits to be obtained by producers $72.1 \%$, C substitution brownies production $(60 \%$ sweet potato $40 \%$ flour) $95.4 \%$ will be obtained, and in $\mathrm{C}$ substitution bread production (60\% sweet potato $40 \%$ flour) producers will get $110 \%$ profit.

\section{H. Consumer Preference with Costs, Acceptance and Benefits}

For the production of pizza substitution, the most preferred by consumers is substitution of $80 \%$ sweet potato [6] $20 \%$ flour, so that if the producer produces according to the level of consumer preference, the profits to be obtained by producers is $72.1 \%$,

Consumer brownies I prefer the substitution of c $60 \%$ sweet potato $40 \%$ flour, to produce substitution, producers will get a profit $95.4 \%$ Thus, the producer will get the maximum benefit.

To produce bread, consumers prefer c $60[4] \%$ sweet potato substitution $40 \%$ flour, so that the cost that must be paid by the producer for this substitution producers will get $110 \%$ profit.

For brownies and bread, the substitution of $d$ with the composition of $80 \%$ sweet potato $20 \%$ flour is very beneficial, but the difference in preferences is so small that it can replace each other between substitution of c $60 \%$ sweet potato $40 \%$ flour and substitution $d$ with the composition of $80 \%$ sweet potato $20 \%$.

When viewed from the average consumer who likes $d$ substitution of brownies with a composition of $80 \%$ sweet potato $20 \%$ flour and substitution c $60 \%$ sweet potato $40 \%$ flour, it is apparent that there is very little difference of only 0.2 . This means that if substitution of c $60 \%$ sweet potato $40 \%$ flour is not available on the market, consumers will consume substitution of $d$ with a composition of $80 \%$ sweet potato $20 \%$ flour.

On the average, bread difference between consumers who like c $60 \%$ substitution of sweet potatoes $40 \%$ flour and substitution d with a composition of $80 \%$ sweet potato $20 \%$ less flour is only 0.1 . Therefore, there are only few consumers are marketed to consume.

\section{CONCLUSION}

Based on the results of research on consumer preferences for processed sweet potato food, it is possible to draw the following conclusions.

1. The pizza consumers prefer pizza with substitution of $80 \%$ sweet potato $20 \%$ flour. The brownies and bread consumers prefer c substitution with a composition of $60 \%$ sweet potatoes and $40 \%$ flour.

2. The profits obtained by producers when producing processed food based on consumer preferences are: producing substitute pizza [15]72.1\%, C substitution brownies production ( $60 \%$ sweet potato $40 \%$ flour) $95.4 \%$ will be obtained, and in $\mathrm{C}$ substitution bread production (60\% sweet potato $40 \%$ flour) producers will get $110 \%$ profit.

3. The relationship between consumer preferences and cost and profit predictions is that it can be a reference for producers in producing processed food substituted with sweet potatoes.

\section{REFERENCES}

[1] "www.deptan.go.id," [Online].

[2] Anonim, "Bahan Lokal Berpotensi Besar," www.kompas.com, 2007.

[3] S. L., Tepung Ubijalar Pembuatan dan Pemanfaatannya, Yogyakarta: Kanisius, 2003.

[4] A. A. C., "Substitusi Tepung Terigu Dengan Tepung Ubi Jalar (Iphomea Batatas L.) Pada Pembuatan Roti Tawar: pengaruh terhadap nilai gizi dan sifat tekstur.," Fakultas Teknologi Pertanian UGM, Yogyakarta, 2007.

[5] A. H. Yusuf M., "UBI Jalar Kaya Antosianin Pilihan Pangan Sehat," puslitbang.bogor.net, Bogor, 2007.

[6] A. A. C., "Substitusi Tepung Terigu Dengan Tepung Ubi Jalar (Iphomea Batatas L.) Pada Pembuatan Roti Tawar: pengaruh terhadap nilai gizi dan sifat tekstu," Fakultas Teknologi Pertanian UGM, Yogyakarta, 2007.

[7] S. D., Teori Mikroekonomi Teriemahan Drs, Rudy Sitompul, Jakarta: Erlangga, 1992.

[8] Soekartawi, Pengantar Agroindustri, Jakarta: PT. Raja Grafindo, 2001.

[9] Kartosapotra, Pengantar Ekonomi Produksi Pertanian, Jakarta: PT. Bumi Nusantara, 1988.

[10] Gilarso, Pengantar Ilmu Ekonomi Bagian, Yogyakarta: Kanisius, 1993.

[11] K. R., "Preferensi Industri Tahu dan tempe terhadap Ukuran dan Warna Biji Kedelai," www.puslittan.bogor.net, Bogor, 2007.

[12] M. N.E., "Analisis Preferensi Konsumen Produk Jelly di Kota Bogor dan implikasinya Terhadap Strategi Pemasaran: Studi 
Kasus Pada CV. Citra Pangan Mandiri," www.puslittan.bogor.net, Bogor, 2008.

[13] M. Hadiguna R.A, "Model Perencanaan Produksi Pada Rantai Pasok Crude Palm Oli Dengan Mempertimbangkan Preferensi \{engambilan Keputusan," Jurnal Teknik Industri, vol. 10, no. 1, pp. 38-49, 2008.

[14] N. Suprianti Y., "Usahatani Ubi Jalar Sebagai Bahan Pangan Alternatif dan Diversifikasi Sumber Karbohidrat," http://www.biogen.litbang.deptan.go.id, Jakarta, 2001.

[15] H. Z. Adi S., "Analisis Sikap Konsumen Terhadap Produk Kecap ABC di Pasar Tradisional Ambal, Kecamatan Ambal Kabupaten Kebumen," Jurnal Surya Agritama, vol. 4, no. (1), pp. 91-98, 2015.

[16] A. Prabowo, "Analisis Sikap Konsumen Teh Botol Sosro, Berdasarkan Atribut-atribut Produk," Jurnal Agrise, vol. 9, no. 1, p. 57, 2009.

[17] S. K. S. Aisyah E., "Analisis Faktor-faktor Preferensi Pelanggan dan Pengaruhnya Terhadap Keputusan Pembelian (Studi Terhadap Pelanggan Indonesia dan Malaysia," 2016.

[18] A. N. F., "SIkap Konsumen Terhadap Produk Donat Berbahan Mocaf Sebagai Pengganti Tepung Terigu," Jurnal Agraris, vol. 1, no. (2), pp. 150-156, 2015.

[19] C. R. R., "Faktor yang Menjadi Preferensi Konsumen Dalam Membeli Produk Frozen Food PERFORMA," Jurnal Manajemen dan Start-Up Bisnis, vol. 1, 2016.

[20] R. Joko, "Studi perilaku Konsumen dan Identifikasi Parameter Bakso Sapi Berdasarkan Preferensi Konsumen di Wilayah DKI Jakarta," Jurnal Teknologi dan Industri Pangan, vol. VI XIII, no. 1, 2002.

[21] N. Suprapti Y., "Usahatani Ubi Jalar Sebagai Bahan Pangan Alternatif dan Diversifikasi Sumber Karbohidrat," www.biogen.litbang.deptan.go.id, Jakarta, 2012. 